\title{
СОЦІАЛЬНО-ВІДПОВІДАЛЬНІ АСПЕКТИ АДМІНІСТРУВАННЯ ПОДАТКІВ: ВАЖЕЛІ ПРОТИДІЇ УХИЛЕННЮ ВІД ОПОДАТКУВАННЯ
}

\author{
DOI: $10.32620 /$ cher.2021.2.05
}

\begin{abstract}
Постановка проблеми. Жодна країна в світі, як би вона не прагнула, не могла, не може і не зможе, судячи по-всьому, позбутися неформальної економіки. Реальність така, що сьогодні, за різними оцінками фахівців, від однієї третини до більшої половини ВНП України створюється в неформальному секторі економіці. Неформальна економіка в Україні - це не окреме явище, а результат системної кризи економіки, він має вплив на всі сфери економічної діяльності, в тому числі на ефективність функціонування податкової системи, що в свою чергу має вплив на стійкість і потужність держави. Зі свого боку однією з ознак дієвості податкової системи є масштаби використання схем ухилення від сплати податків. Метою статті $є$ дослідження процесів адміністрування податків з позиції забезпечення соціально-відповідального сервісу органів державної фіскальної служби України, використання важелів протидії ухиленню від оподаткування, надання рекомендацій зменшення обсягів неформального сектору економіки та основних схем ухилення від сплати податків в Україні. Предмет дослідження - безпосередньо неформальний сектор та методи запобігання одного 3 наслідків ухилення від сплати податків. Методи, використані в дослідженні: системний аналіз, економіко-статистичні методи, опрацювання інформації, метод логічного узагальнення результатів, експертних оцінок тощо. Виклад основного матеріалу. У статті досліджено основні тенденції зайнятості населення в неформальному секторі національної економіки. Була розкрита сутність поняття ухилення від сплати податків та причини виникнення. Зазначено найпоширеніші схеми, внаслідок яких бюджет України зазнає найбільших втрат, в ході чого були виділені пропозиції удосконалення податкового адміністрування як вагомого важеля мінімізації податкових правопорушень у сфері ухилення від сплати податків в рамках неформального сектору економіки. Практичне значення одержаних результатів полягає у можливості використання розроблених рекомендацій для самостійного аналізу економічного становища в Україні. Висновкита перспективи подальших дослідження. Проведений аналіз різних механізмів ухилення оподаткування показав, що більшість 3 них пов'язано 3 відсутністю контролю з боку фіскальних органів, слабким рівнем розвитку системи електронного адміністрування товарів та коштів між суб’єктами господарювання та з нездатністю правильно здійснювати нарахування та сплату податкових платежів. Тому з запропонованих рекомендацій задля зменшення обсягів та втрат бюджету від схем ухилення від сплати податків в рамках неформального сектору економіки, можна виділити, що ключовим $є$ послідовність. Перш за все, відповідно до пріоритетів, що випливають із чинного рейтингу, це заходи, спрямовані на боротьбу з агресивним податковим плануванням. За цим має йти завершення реформи адміністрування ПДВ та, що важливо, подальше відчутне зменшення частки держави, яке має забезпечити фіскальний простір для значного зменшення податку на доходи та скасування податку на працю, однак це потребує більше часу через різні проблеми в країні.
\end{abstract}

Ключові слова:

неформальний сектор економіки, ухилення від сплати податків, адміністрування податків, офшорні схеми.

\section{SOCIALLY RESPONSIBLE ASPECTS OF TAX ADMINISTRATION: LEVERS TO COMBAT TAX AVOIDANCE}

Formulation of the problem. No country in the world, no matter how hard it tries, could not, cannot and will not be able to get rid of the informal economy. The reality is that today, according to various experts, from one third to more than half of Ukraine's GDP is created in the informal sector of the economy. The informal economy in Ukraine is not a separate phenomenon, but the result of a systemic economic crisis, it affects all areas of economic activity, in-

${ }^{1}$ Ліхоносова Ганна Сергіївна, д-р екон. наук, професор кафедри фінансів, обліку і оподаткування, Національний аерокосмічний університет ім. М. Є. Жуковського «Харківський авіаційний інститут», м. Харків, Україна.

Likhonosova Ganna, Doctor of Economic Sciences, Professor of Finance, accounting and taxation Department National Aerospace University «Kharkiv Aviation Institute», Kharkiv, Ukraine.

ORCID ID: 0000-0001-6552-8920

e-mail: a.likhonosova@gmail.com

${ }^{2}$ Мартиненко Катерина Романівна, студентка спеціальності 071 «Облік і оподаткування», Національний аерокосмічний університет ім. М. С. Жуковського «Харківський авіаційний інститут», м. Харків, Україна.

Martynenko Kateryna, student of 071 Accounting and Taxation Speciality, National Aerospace University «Kharkiv Aviation Institute», Kharkiv, Ukraine.

ORCID ID: 0000-0003-3340-5090

e-mail: k.r.martynenko@student.khai.edu 
cluding the efficiency of the tax system, which in turn affects the stability and power of the state. For its part, one of the signs of the effectiveness of the tax system is the scale of the use of tax evasion schemes. The purpose of the article is to study the processes of tax administration from the standpoint of providing socially responsible service of the state fiscal service of Ukraine, the use of levers to combat tax evasion, provide recommendations for reducing the informal sector and the main schemes of tax evasion in Ukraine. The subject of the study is the informal sector and methods of preventing one of the consequences - tax evasion. Methods used in the study: systems analysis, economic and statistical methods, information processing, the method of logical generalization of results, expert assessments, etc. Presenting main material. The article examines the main trends in employment in the informal sector of the national economy. The essence of the concept of tax evasion and the reasons for it were revealed. The most common schemes as a result of which the budget of Ukraine suffers the greatest losses are indicated, during which proposals to improve tax administration as a significant lever for minimizing tax offenses in the field of tax evasion within the informal sector of the economy were identified. The practical significance of the obtained results lies in the possibility of using the developed recommendations for independent analysis of the economic situation in Ukraine. Conclusions and further prospects of the study. An analysis of various tax evasion mechanisms has shown that most of them are due to lack of control by fiscal authorities, weak level of development of the system of electronic administration of goods and funds between businesses and the inability to properly calculate and pay taxes. Therefore, from the proposed recommendations to reduce the amount and loss of the budget from tax evasion schemes within the informal sector of the economy, we can highlight that consistency is key. First of all, according to the priorities arising from the current rating, these are measures aimed at combating aggressive tax planning. This should be followed by the completion of VAT administration reform and, importantly, a further significant reduction in the share of the state, which should provide fiscal space for a significant reduction in income tax and abolition of labor tax, but this takes more time due to various problems in the country.

Key words:

informal sector of the economy, tax evasion, tax administration, offshore schemes.

\section{СОЦИАЛЬНО-ОТВЕТСТВЕННЫЕ АСПЕКТЫ АДМИНИСТРИРОВАНИЕ НАЛОГОВ: РЫЧАГИ ПРОТИВОДЕЙСТВИЯ УКЛОНЕНИЯ ОТ НАЛОГООБЛОЖЕНИЯ}

Постановка проблемы. Ни одна страна в мире, как бы она ни старалась, не могла, не может и не сможет избавиться неформальной экономики. Реальность такова, что сегодня, по разным оценкам специалистов, от одной трети до более половины ВНП Украины создается в неформальном секторе экономике. Неформальная экономика в Украине - это не отдельное явление, а результат системного кризиса экономики, он влияет на все сферы экономической деятельности, в том числе на эффективность функционирования налоговой системы, что в свою очередь влияет на устойчивость и мощность государства. Со своей стороны, одним из признаков действенности налоговой системы являются масштабы использования схем уклонения от уплаты налогов. Целью статьи является исследование процессов администрирования налогов с позиции обеспечения социальноответственного сервиса органов государственной фискальной службы Украины, использование рычагов противодействия уклонению от налогообложения, предоставление рекомендаций уменьшение объемов неформального сектора экономики и основных схем уклонения от уплаты налогов в Украине. Предмет исследования - непосредственно неформальный сектор и методы предотвращения одного из наследствий - уклонение от уплаты налогов. Meтоды, использованные в исследовании: системный анализ, экономико-статистические методы, обработки информации, метод логического обобщения результатов, экспертных оценок и др. Изложение основного материала. В статье исследованы основные тенденции занятости населения в неформальном секторе национальной экономики. Была раскрыта сущность понятия уклонения от уплаты налогов и причины возникновения. Указано распространенные схемы, в результате которых бюджет Украины испытывает наибольшие потери, в ходе чего были выделены предложения усовершенствования налогового администрирования как весомого рычага минимизации налоговых правонарушений в сфере уклонения от уплаты налогов в рамках неформального сектора экономики. Практическое значение полученных результатов заключается в возможности использования разработанных рекомендаций для самостоятельного анализа экономического положения в Украине. Выводы исследования и перспективы дальнейших исследований. Проведенный анализ различных механизмов уклонения налогообложения показал, что большинство из них связано с отсутствием контроля со стороны фискальных органов, слабым уровнем развития системы электронного администрирования товаров и средств между субъектами хозяйствования и неспособность правильно осуществлять начисление и уплату налоговых платежей. Поэтому с по-предлагаемых рекомендаций для уменьшения объемов и потерь бюджета от схем уклонения от уплаты налогов в рамках неформального сектора экономики, можно выделить, что ключевым является последовательность. Прежде всего, в соответствии с приоритетами, вытекающие из действующего рейтинга, это меры, направленные на борьбу с агрессивным налоговым планированием. По этим должно последовать завершение реформы администрирования НДС и, что важно, подальше ощутимое уменьшение доли государства, которое должно обеспечить фискальное пространство для значительного уменьшения налога на доходы и отмены налога на труд, однако это требует больше времени из-за различных проблем в стране.

Ключевые слова:

неформальный сектор экономики, уклонение от уплаты налогов, администрирование налогов, оффшор- 
Постановка проблеми. В Україні в останні роки спостерігається погіршення загальної економічної ситуації, значні затримки в реальному житті від існуючих стандартів і високий ступінь незадоволеності населення діяльністю уряду. Наприклад, надмірна інфляція, зниження продуктивності, вимушене безробіття та неповна зайнятість, низький рівень заробітної плати, велика нездатність адаптуватися до нових умов в системі соціального захисту, відсутність законодавчих важелів призводять до реального зниження доходів домогоспо-дарств, посилення різноманітності державної власності та поширення бідності [1, с. 1]. Зрозуміло, що тіньова економіка в таких економічних умовах набирає обертів.

Актуальність тематики дослідження пов'язана не тільки 3 важливістю фінансових результатів в економічному розвитку підприємств, але й невирішеністю багатьох проблем, у тому числі відсутності єдиного підходу до розкриття змісту поняття «фінансовий результат», неповноти нормативно-законодавчої бази з питань обліку, аналізу та аудиту фінансових результатів, недосконалість сучасної концепції систематизації фінансових результатів тощо.

Аналіз останніх досліджень і публікацій. Для повного розуміння будь-якого феномена необхідно, насамперед, знайти його точне сутнісне визначення. 3 визначенням терміну «неформальний сектор економіки» виникають деякі труднощі через різне його трактування фахівцями $з$ економіки. Проблеми неформальної економіки досліджували такі вчені, як I. Ангелко [1, с. 2], П. Вавілов [3, с. 8], Т. Кузнецова [7, с. 3], Е. Лібанова [8, с. 245], В. Попович $[12$, с. 6-7] та інших. Щодо основної складової цього явища, а саме ухилення від оподаткування, масштаби якого суттєво впливають на макроекономічні показники держави, у науковій літературі відсутній єдиний підхід стосовно тракту-вання сутності цього поняття, причин його виникнення та шляхів подолан-ня. Поперше, думки науковців розділилися стосовно законності таких дій. Так, С. О. Баранов [2, с. 1], I. А. Майбуров, А. М. Соколовська [9, с. 385], О. В. Мірошніченко [11, с. 89] та Т. Л. Томнюк [14, c. 279] вважають, що при ухиленні від оподаткування мають місце тільки незаконні дії платника податків. А Н. І. Главацька [5, с. 22] зазначає, що це можуть бути дії як з порушенням, так і не порушенням чинного законодавства. По-друге, немає єдиної думки стосовно усвідомленості відповідних дій платником податків. Так, А. П. Вавілов [6] вважає, що обов'язковою ознакою ухилення від оподаткування є свідомі дії платника податків, спрямовані на зниження розміру податкових відрахувань або їх уникнення. А науковці І. А. Майбуров, А. М. Соколовська [9, с. 385] та О. В. Мірошніченко [11, c.89] зазначають, що також це можуть бути ненавмисні дії внаслідок неуважності [15], технічних помилок або інших факторів.

Метою статті $\epsilon$ дослідження процесів адміністрування податків 3 позиції забезпечення соціально-відповідального сервісу органів державної фіскальної служби України, використання важелів протидії ухиленню від оподаткування, надання рекомендацій зменшення обсягів неформального сектору економіки та основних схем ухилення від сплати податків в Україні

Виклад основного матеріалу дослідження. Неформальна економіка охоплюе більше половини світової робочої сили і більш 90\% мікро і малих підприємств у всьому світі. В Україні спостерігається приплив верств населення 3 формального сегмента економіки в тіньовий, що $є$ реальною проблемою, що загрожує безпеці, суспільній моралі і благополуччю людей.

Розробку методологічних підходів статистичного дослідження зайнятості у вітчизняному неформальному секторі економіки було розпочато Держкомстатом у 1997 році. 3 урахуванням досвіду інших країн, міжнародних стандартів, матеріалів відповідних статистичних обстежень, розроблено національну методику визначення зайнятості населення у неформальному секторі економіки.

3 урахуванням положень керівних принципів щодо статистичного визначення неформальної зайнятості, що були прийняті на 17-й Міжнародній конференції статистиків праці у 2003 році, а також відповідно до Методологічних положень щодо визначення неформальної зайнятості населення, до неформально зайнятих належать такі категорії населення $[10$, с. 8$]$ :

- особи, які працюють за власний рахунок (самозайнятих), та роботодавців, які працюють на власних підприємствах у неформальному секторі;

- безкоштовно працюючі члени сімей, незалежно від того, працюють вони на підприємствах формального чи неформального секторів;

- наймані працівники, які виконують неформальні роботи, тобто не охоплені правовим чи соціальним захистом як працюючі особи, не мають права на інші пільги, пов'язані із зайнятістю (наприклад завчасне повідомлення про звільнення, вихідна допомога, щорічна оплачувана відпустка або лікарняний), а також 
наймані домашні працівники у домогосподарствах;

- члени неформальних виробничих кооперативів;

- самозайняті працівники, що виробляють товари виключно для власного кінцевого споживання домогосподарства (якщо вони враховуються в зайнятому населенні).
Отже, виходячи 3 наданих категорій, Державний комітет статистики збирає статистичні дані, які групує за такими критеріями, як: за віком, за статтю, за місцем проживання та за видами економічної діяльності. Обсяги неформально зайнятого населення за даними критеріями в Україні наведено в таблиці 1.

Таблиця 1: Неформальне зайняте населення за ознаками класифікації, 2017 - 2019 рр.

\begin{tabular}{|c|c|c|c|c|c|c|}
\hline \multirow[b]{3}{*}{ Показник } & \multicolumn{6}{|c|}{ Рік } \\
\hline & \multicolumn{2}{|c|}{2017} & \multicolumn{2}{|c|}{2018} & \multicolumn{2}{|c|}{2019} \\
\hline & Тис осіб & $\begin{array}{c}\text { у \% до зага- } \\
\text { льної кілько- } \\
\text { сті зайнятого } \\
\text { населення } \\
\text { віком } 15-70 \\
\text { років } \\
\end{array}$ & Тис осіб & $\begin{array}{c}\text { у \% до зага- } \\
\text { льної кілько } \\
\text { сті зайнятог } \\
\text { населення } \\
\text { віком } 15-70 \\
\text { років } \\
\end{array}$ & Тис осіб & $\begin{array}{c}\text { у \% до зага- } \\
\text { льної кілько- } \\
\text { сті зайнятого } \\
\text { населення } \\
\text { віком 15-70 } \\
\text { років } \\
\end{array}$ \\
\hline $\begin{array}{l}\text { Кількість неформально } \\
\text { зайнятого населення } \\
\text { віком } 15-70 \text { років }\end{array}$ & 3695,6 & $22,9 \%$ & 3541,3 & $21,6 \%$ & 3460,4 & $20,9 \%$ \\
\hline \multicolumn{7}{|c|}{ За статтю } \\
\hline Чоловіки & 2180,9 & $26,0 \%$ & 2071,8 & $24,5 \%$ & 2057,1 & $23,8 \%$ \\
\hline Жінки & 1514,7 & $19,5 \%$ & 1469,5 & $18,6 \%$ & 1403,3 & $17,7 \%$ \\
\hline \multicolumn{7}{|c|}{ За місцем проживання: } \\
\hline Міська місцевість & 1697,2 & $15,3 \%$ & 1599,6 & $14,2 \%$ & 1586,2 & $13,9 \%$ \\
\hline Сільська місцевість & 1998,4 & $39,6 \%$ & 1941,7 & $38,2 \%$ & 1874,2 & $36,3 \%$ \\
\hline \multicolumn{7}{|c|}{$\begin{array}{c}\text { За видами економічної діяльності ( у \% до кількості неформально зайнятого населення віком } \\
15-70 \text { років) }\end{array}$} \\
\hline & Тис осіб & $\%$ & Тис осіб & \begin{tabular}{l|l}
$\%$ & \\
\end{tabular} & Тис осіб & $\%$ \\
\hline $\begin{array}{l}\text { сільське господарство, } \\
\text { лісове господарство та } \\
\text { рибне господарство }\end{array}$ & 1555,85 & 42,1 & 1519,22 & 42,9 & 1463,75 & 42,3 \\
\hline промисловість & 206,95 & 5,6 & 194,77 & 5,5 & 204,16 & 5,9 \\
\hline будівництво & 594,99 & 16,1 & 563,07 & 15,9 & 588,27 & 17,0 \\
\hline $\begin{array}{l}\text { оптова та роздрібна } \\
\text { торгівля; ремонт автот- } \\
\text { ранспортних засобів і } \\
\text { мотоциклів }\end{array}$ & 724,34 & 19,6 & 644,52 & 18,2 & 598,65 & 17,3 \\
\hline $\begin{array}{l}\text { транспорт, складське } \\
\text { господарство, поштова } \\
\text { та кур'єрська діяльність }\end{array}$ & 121,95 & 3,3 & 148,73 & 4,2 & 134,96 & 3,9 \\
\hline $\begin{array}{l}\text { тимчасове розміщуван- } \\
\text { ня й організація харчу- } \\
\text { вання }\end{array}$ & 88,69 & 2,4 & 77,91 & 2,2 & 89,97 & 2,6 \\
\hline $\begin{array}{l}\text { інші види економічної } \\
\text { діяльності }\end{array}$ & 402,82 & 10,9 & 393,08 & 11,1 & 380,64 & 11,0 \\
\hline
\end{tabular}

Джерело: розроблено авторами на підставі [10]

Дані показники лише підтверджують, що незважаючи на те, що зайняте населення у неформальному секторі економіки за останні роки зменшується, як за основним показником, так і за деякими критеріями, рівень тінізації економіки в Україні став вже масовим явищем, а не епізодичним. Виходячи 3 цього, зазначимо, що основними причинами поширення неформальної зайнятості населення, є:

- дефіцит гідної та високо оплачуваної роботи в офіційному секторі економіки;
- недосконалість нормативно-правової бази, яка регулює ринок праці та зайнятості;

- слабкий соціальний захист та порушення роботодавцем прав найманих працівників;

- високе навантаження на фонд заробітної плати та бажання уникнути високих податків;

- зміна трудових мотивацій в частині більшої самостійності в роботі та вільного розпорядження часом; 
- нерегульована трудова міграція населення, представники якої часто стають неформально зайнятими [1, с. 125].

Основною складовою цього явища $є$ ухилення від оподаткування, масштаби якого суттєво впливають на макроекономічні показники держави. Отже боротьба з ухиленням від сплати податків $\epsilon$ пріоритетною для органів державної влади, так як чим більшими є обсяги ухилення від оподаткування, тим слабкішою $\epsilon$ держава внаслідок недофінансованості державного бюджету, що проявляється, зокрема, в дефіциті фінансування соціальної сфери, а отже, низькому рівні соціального захисту населення. Тому з метою забезпечення сталого розвитку держави, зокрема, є необхідним розв'язання проблеми ухилення від сплати податків.

Ухилення від сплати податків являє собою свідомі й умисні дії платника податків, спрямовані на повну чи часткову несплату податків, зборів або інших обов'язкових платежів до бюджету, які можуть бути як незаконними, так і в межах чинного законодавства.

Серед основних чинників, котрі спонукають платників уникати сплати податків, виді- ляють: кількість податків та рівень податкових ставок; складність у розрахунках податкових сум; високий рівень нестабільності (постійно змінюються не лише ставки оподаткування, а й види податків); нераціональна структура оподаткування (висока частка непрямих податків, низька частка особистого прибуткового податку і високі нарахування на фонд заробітної плати); рівень суспільної свідомості щодо необхідності сплачувати податки; рівень довіри платників до владних структур, котрі виконують функцію розподілу коштів, отриманих від податків; рівень корупції у державі.

Як відомо, в кожній державі існують свої способи та методи несплати податків. Аналізуючи найбільш актуальні для України інструменти ухилення від сплати податків, було здійснено оцінювання їхніх розмірів. Слід зазначити, що частина схем пов'язані між собою, обсяги одних частково враховані у обсягах інших, тому загальні втрати бюджету від всіх схем будуть дещо меншими, ніж їх математична сума. Перелік схем та розкриття їх сутності представлено у таблиці 2.

Таблиця 2: Схеми ухилення від оподаткування, які усуваються шляхом відповідального адміністрування податків

\begin{tabular}{|c|c|c|}
\hline № & Схема ухилення & Сутність \\
\hline 1 & 2 & 3 \\
\hline 1 & $\begin{array}{l}\text { Переміщення } \\
\text { прибутку до } \\
\text { «податкових } \\
\text { гаваней» } \\
\text { («офшорів») }\end{array}$ & $\begin{array}{l}\text { використання з боку платників податків всіх дозволених законом засобів уникнення } \\
\text { від сплати податків, тобто легальна мінімізація податкових зобов’язань, зокрема } \\
\text { агресивне податкове планування, податкова оптимізація, зловживання правом або } \\
\text { використання недобросовісних практик, у тому числі використання розбіжностей, } \\
\text { колізій та прогалин між різними системами оподаткування, а також пільгового опо- } \\
\text { даткування окремих видів діяльності або доходу, маніпулювання статусами резиде- } \\
\text { нтності, за допомогою якого здійснюється переведення прибутку українського по- } \\
\text { ходження без відповідного оподаткування податком на прибуток підприємств до } \\
\text { країн з нижчими або нульовими ставками для зменшення податкового тягаря. }\end{array}$ \\
\hline 2 & \begin{tabular}{l}
\multicolumn{2}{l}{ Розкрадання } \\
податку на до- \\
дану \\
(ПДВ)
\end{tabular} & $\begin{array}{l}\text { - фіктивне підприємництво, зокрема карусельні схеми - схема незаконного відшко- } \\
\text { дування ПДВ коли товари багаторазово перепродаються і експортуються, внаслідок } \\
\text { чого експортер відшкодовує ПДВ, а постачальники, не сплативши податок, зника- } \\
\text { ють. Один і той же товар може курсувати всередині країни по колу, дозволяючи ви- } \\
\text { користовувати відшкодування ПДВ як інструмент злочинного бізнесу; } \\
\text { - формування схемного податкового кредиту («скрутки» або схемний ПдВ) - підп- } \\
\text { риємство (у більшості випадків легальний імпортер) офіційно імпортує товари до } \\
\text { України, сплачуючи до бюджету ПдВ на імпорт та отримуючи, відповідно, подат- } \\
\text { ковий кредит на цю суму. Далі товар реалізується всередині країни за готівкові кош- } \\
\text { ти, але по документах все ще залишаючись на товарному обліку підприємства. }\end{array}$ \\
\hline 3 & $\begin{array}{l}\text { Порушення ми- } \\
\text { тних правил, } \\
\text { контрабанда та } \\
\text { корупція на кор- } \\
\text { доні }\end{array}$ & $\begin{array}{l}\text { - викривлене декларування - маніпулювання даними; } \\
\text { - подвійна контрабанда - незаконне переміщення товарів через митний кордон поза } \\
\text { митним контролем; } \\
\text { - зловживання пільгами - маскування ввезення промислових партій товарів на мит- } \\
\text { ну територію України під поштові та кур'єрські відправлення або під виглядом осо- } \\
\text { бистого імпорту або провозу особистих речей - ввезення фізичними особами товарів } \\
\text { у ручній поклажі або у супроводжуваному багажі; } \\
\text { - перерваний транзит - товар ввозиться на територію України (або вивозиться з неї) } \\
\text { за митними режимами що не передбачають сплату митних платежів (транзит; тим- } \\
\text { часове ввезення або вивезення; митний склад; переробка на митній території або за } \\
\text { межами митної території) та зникає або підлягає фіктивному вивезенню. }\end{array}$ \\
\hline
\end{tabular}




\begin{tabular}{|c|c|c|}
\hline 1 & 2 & T \\
\hline 4 & $\begin{array}{l}\text { Індустрія «кон- } \\
\text { вертаційних } \\
\text { центрів» }\end{array}$ & $\begin{array}{l}\text { використовують фірми-прокладки (фірми-одноденки), та відкриті на них рахунки в } \\
\text { банках }\end{array}$ \\
\hline 5 & Контрафакт & $\begin{array}{l}\text { фальсифіковані товари або новий продукт, який створений на основі існуючого ори- } \\
\text { гіналу з порушенням інтелектуальних прав. }\end{array}$ \\
\hline 6 & $\begin{array}{l}\text { Схеми } \\
\text { ринку } \\
\text { землі }\end{array}$ & $\begin{array}{l}\text { значна частина орендних договорів не реєструється належним чином, відповідно } 3 \\
\text { доходів орендодавців не сплачується ПДФО. Також, ймовірно, чимала частина зем- } \\
\text { левласників, які обробляють наділи власноруч, не сплачує податків } 3 \text { вирощеної } \\
\text { продукції навіть коли розмір ділянки перевищує } 2 \text { га, щодо яких діє встановлена } \\
\text { законом пільга. }\end{array}$ \\
\hline 7 & $\begin{array}{l}\text { Тіньові заробітні } \\
\text { плати }\end{array}$ & $\begin{array}{l}\text { - метою оптимізації податкового навантаження більша частина ФЗП виписується у } \\
\text { вигляді зарплати на одного або кількох вищих керівників таким чином, аби зменши- } \\
\text { ти виплати ЄСВ за рахунок значного перевищення верхньої межі його нарахування; } \\
\text { - оплата праці за рахунок «чорного кешу», сгенерованого самим підприємством; } \\
\text { - використання псевдо-ФОП } 3 \text { гр. для отримання готівки; } \\
\text { - робота через конвертаційні центри. }\end{array}$ \\
\hline 8 & $\begin{array}{l}\text { Ухилення від } \\
\text { сплати податків } \\
\text { за допомогою } \\
\text { CСО }\end{array}$ & $\begin{array}{l}\text { - юридичні особи не оформлюють працівників, а співпрацюють з ФОП } 3 \text { групи єди- } \\
\text { ного податку за цивільно-правовими договорами (ЦПД), отримання готівки юриди- } \\
\text { чними особами за допомогою ФОП } 3 \text { групи ЄП. } \\
\text { - ФОП } 1 \text { та } 2 \text { групи спрощеної системи оподаткування реалізують товари та послуги, } \\
\text { при цьому суттєво занижуючи свою виручку. }\end{array}$ \\
\hline
\end{tabular}

На основі викладеної характеристики кожної зі схем, та рис.1, можна прийти до підсумку порівняльного аналізу, що співвідношення між наведеними там цифрами в основному під-

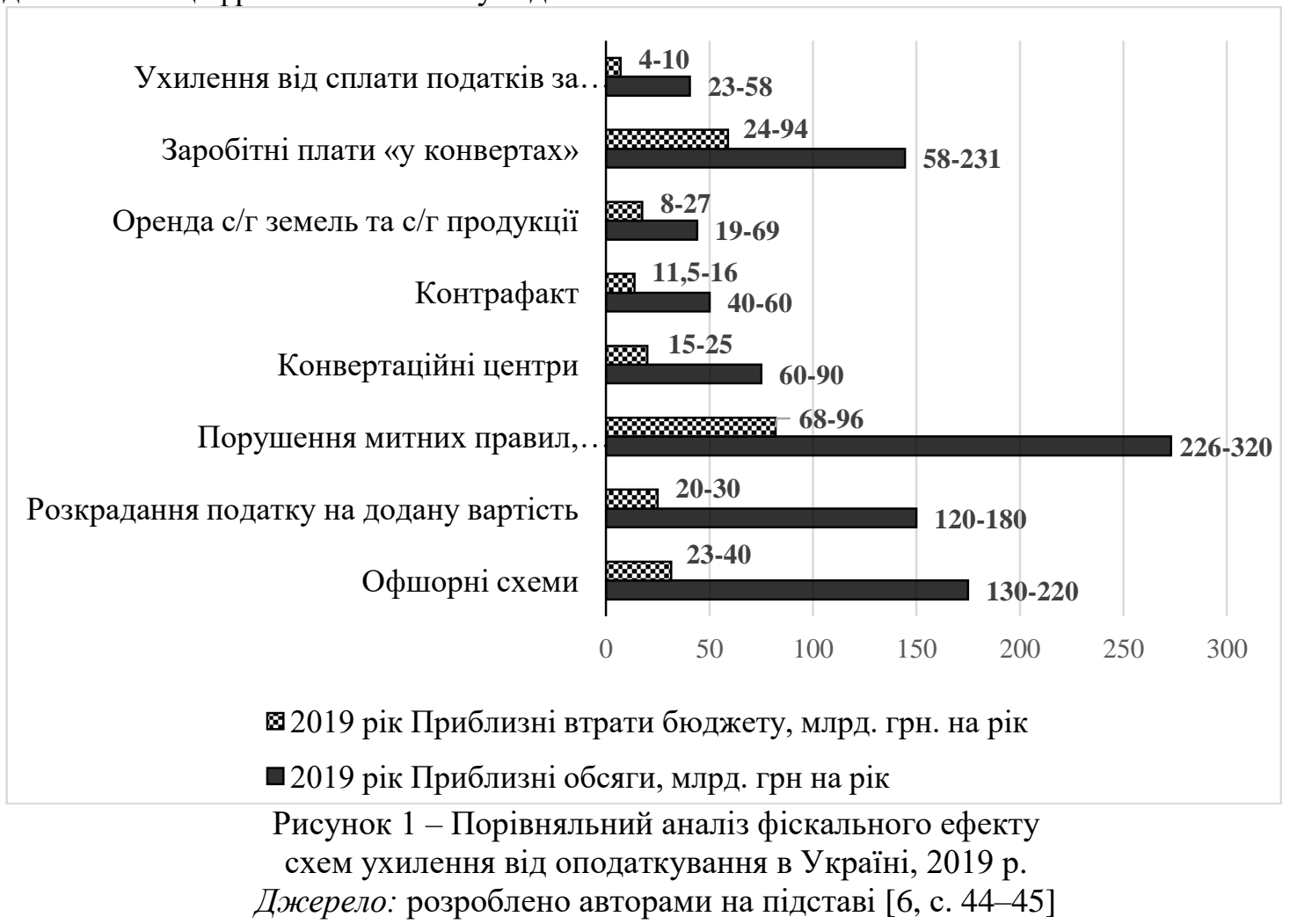

Станом на 2019 рік бодай й незначне економічне відновлення призвело до суттєвого зростання обсягів імпорту, як офіційного так й неформального (що базуються на порушенні митних правил, контрабанді та корупції на кордоні). тверджують міркування щодо структури уникнення податків в Україні. 
Офшорні схеми, внаслідок високої та висхідної вартості обслуговування, що обумовлюється новими світовими стандартами податкової прозорості (antiBEPS, FATCA, ATAD та інші), все більш отримують ознаки «елітарності», тобто залишаються доступними великим українським компаніям та заможним українцям. При цьому обсяги втечі прибутків за кордон все ще залишаються надто високими та сягають до 220 мільярдів гривень на рік [6].

3 цієї ж причини не спостерігається поліпшення у питанні протидії незаконному обігу контрафактних товарів, де зазвичай домінують підакцизні товари (спирт, алкогольні напої, тютюнові вироби та нафтопродукти). Більш того, політика жвавого зростання розмірів акцизного податку, що стимулюється як зобов'язаннями України в рамках угоди з $\mathrm{CC}$, так й пошуками 3 боку Уряду та парламенту «популярних» шляхів покриття касових розривів державного бюджету, зробила Україну лідером виробництва та контрабанди сигарет до ЄС.

Отже, 3 огляду на швидкий розвиток процесу європейської інтеграції, вихід на нові рин- ки товарів і послуг, важливу роль в загальній стратегії розвитку уряду відіграє аналіз та ідентифікація всіляких схем ухилення від сплати податків і формування незаконних фінансових потоків.. Проведений аналіз показав наявність різних інструментів для приховування оподатковуваного прибутку економічними суб' єктами, переважна більшість 3 яких пов'язана 3 недосконалістю існуючої системи нарахування та сплати податкових платежів. Відсутність належного контролю $з$ боку податкових органів, слабкий розвиток електронної системи обліку перевезення вантажів і коштів між різними фінансовими агентами, значний рівень корупції в державних контролюючих, митних та податкових органах лише поглиблює ці процеси та сприяє зростанню їх обсягів.

Тому, задля скорочення обсягів використання цих інструментів ухилення від оподаткування та втрат бюджету, від ненадходження коштів, доцільно запропоновувати рекомендації для покращення економічного становища країни. Запропоновані рекомендації представлені у таблиця 3.

Таблиця 3: Удосконалення адміністрування податків в системі схем ухилення від оподаткування

\begin{tabular}{|c|c|}
\hline $\begin{array}{l}\text { № } \\
\Pi / \Pi\end{array}$ & $\begin{array}{c}\text { Шляхи удосконалення адміністрування податків щодо } \\
\text { усунення схем ухилення від оподаткування }\end{array}$ \\
\hline 1 & 2 \\
\hline & $\begin{array}{c}\text { Уникнення від оподаткування за експортно-імпортними операціями, } \\
\text { зокрема за допомогою офшорних схем }\end{array}$ \\
\hline 1 & $\begin{array}{l}\text { активізувати міжнародне співробітництво з питань захисту національної податкової бази від трансна- } \\
\text { ціональних схем уникнення сплати податків, а саме приєднання до процедури автоматичного обміну } \\
\text { фінансової інформації за міжнародним стандартом Common Reporting Standard OECP (CRS), так як це } \\
\text { дієвим інструментом досягнення податкової прозорості. Очікується, що найближчим часом Україна все } \\
\text { ж таки приєднається до цього, адже цей стандарт забезпечить прозорість руху капіталу та надасть дер- } \\
\text { жаві можливість зберігати суверенітет над податковою базою своїх резидентів незалежно від місця } \\
\text { зберігання ними капіталу }\end{array}$ \\
\hline 2 & $\begin{array}{l}\text { запровадження посиленої фінансової відповідальності за приховування доходів в офшорних юрисдик- } \\
\text { ціях }\end{array}$ \\
\hline 3 & $\begin{array}{l}\text { сконцентрувати міжнародний інструментарій захисту національної податкової бази від транснаціона- } \\
\text { льних схем уникнення сплати податків в окремому потужному підрозділі податкової служби } 3 \text { належ- } \\
\text { ною чисельністю та відповідним рівнем підготовки персоналу, завдяки ТЦУ, MLI }\end{array}$ \\
\hline & Ухиляння/уникнення від сплати ПДВ \\
\hline 1 & $\begin{array}{l}\text { покращення поточних можливостей контролюючих органів (фіскальної та митної служб). Потрібна } \\
\text { комплексна реформа контролюючих органів, яка включатиме і ліквідацію податкової міліції та всіх } \\
\text { інших підрозділів різних органів по боротьбі із економічними злочинами та створення єдиного аналі- } \\
\text { тичного Бюро економічної безпеки }\end{array}$ \\
\hline 2 & автоматична система моніторингу (СМКОР) потребує модернізації \\
\hline & Контрафакт \\
\hline 1 & $\begin{array}{l}\text { Україні необхідно приєднатися до Протоколу про ліквідацію незаконної торгівлі тютюновими вироба- } \\
\text { ми (далі - Протокол), метою якого визначено «ліквідація всіх форм незаконної торгівлі тютюновими } \\
\text { виробами» (ст. 3), зокрема шляхом контролю усього ланцюжка поставок. }\end{array}$ \\
\hline 2 & $\begin{array}{l}\text { Уряду потрібно провести роботу «над помилками» в ході підбивання підсумків виконання Стратегії у } \\
\text { сфері протидії незаконному виробництву та обігу тютюнових виробів на період до } 2021 \text { року та до кін- } \\
\text { ця поточного року розробити та затвердити новий якісний програмний документ }\end{array}$ \\
\hline & Тіньова оренда с/г земель та сільгосппродукції \\
\hline 1 & Виділити земельний податок та податок на нерухомість з єдиного податку, в тому числі 4 гр. \\
\hline 2 & $\begin{array}{l}\text { Дозволити органам місцевого самоврядування вирішувати питання із встановленням на їхній території } \\
\text { пільг з земельного податку для пенсіонерів, відповідно скоригувавши вищеозначені субсидії }\end{array}$ \\
\hline
\end{tabular}




\begin{tabular}{|c|l|}
\hline 1 & \multicolumn{1}{c|}{ Продовження табл. 3} \\
\hline 3 & $\begin{array}{l}\text { Запровадити норму, за якою сплачений податок на землю зараховується при нарахуванні та сплаті } \\
\text { ПДФО, таким чином, аби сумлінний платник не постраждав }\end{array}$ \\
\hline 4 & $\begin{array}{l}\text { Створення Комплексної системи контролю за ланцюжком постачання ризикових категорій товарів } \\
\text { шляхом модернізації діючої системи електронного адміністрування ПДВ (СЕА ПДВ) }\end{array}$ \\
\hline \multicolumn{1}{|c|}{ Заробітні плати «у конвертах» } \\
\hline 1 & $\begin{array}{l}\text { Суттєво знизити навантаження на фонд оплати праці, до цільового показника у 20\% сукупно (замість } \\
\text { поточних 41.5\% номінал), компенсуючи недонадходження до бюджету за рахунок скорочення неефек- } \\
\text { тивних видатків бюджету та модифікацією податків на землю та майно (збільшуючи їх долю у ВВП) }\end{array}$ \\
\hline 2 & $\begin{array}{l}\text { Працівники у частині випадків не бажають офіційного оформлення через бажання отримувати субси- } \\
\text { дію на житлово-комунальні послуги. }\end{array}$ \\
\hline 3 & Лібералізувати архаїчне трудове законодавство, привести його до сучасних реалій.
\end{tabular}

$$
\text { Джерело: розроблено авторами на підставі [6, с. 6-41] }
$$

Окрім рекомендацій, наданих за відповідними інструментами ухилення/уникнення від оподаткування, 3 метою мінімізації обсягів схем - загальною рекомендацією до усіх розділів є інституційна реформа податкової та митної служби, перенабір співробітників на відкритих конкурсах та забезпечення їм гідних заробітних плат.

Висновки та перспективи подальших досліджень. Проведений аналіз різних механізмів ухилення оподаткування показав, що більшість 3 них пов'язано з відсутністю контролю з боку фіскальних органів, слабким рівнем розвитку системи електронного адміністрування товарів та коштів між суб'єктами господарювання та 3 нездатністю правильно здійснювати нарахування та сплату податкових платежів. Тому з запропонованих рекомендацій задля зменшення обсягів та втрат бюджету від схем ухилення від сплати податків в рамках неформального сектору економіки, можна виділити, що ключовим є послідовність. Зокрема, якщо йдеться про фіскальні цілі, то з різних причин - управлінських, економічних, соціально-політичних та організаційних — найкращий спосіб діяти - це щоразу зосереджуватись на найбільших схемах ухилення від сплати податків, змінюючи пріоритети залежно від змін у реальному житті. 3 цісї точки зору, інструменти, здатні значно зменшити масштаби схем, уже існують або перебувають на етапі розробки. Перш за все, відповідно до пріоритетів, що випливають із чинного рейтингу, це заходи, спрямовані на боротьбу з агресивним податковим плануванням: податок на виведений капітал, заходи із протидії розмиванню податкової бази та переміщенню прибутків за кордон (BEPS), інституційні реформи ДФС та митної служби, заходи європейської спільноти, а також створення Бюро економічної безпеки України замість недієздатної й корумпованої податкової міліції. За цим має йти завершення реформи адміністрування ПДВ та, що важливо, подаль- ше відчутне зменшення частки держави, яке має забезпечити фіскальний простір для значного зменшення податку на доходи та скасування податку на працю, однак це потребує більше часу через різні проблеми в країні.

\section{Література}

1. Ангелко I. В. Неформальна зайнятість населення України в сучасних умовах. Украӥнський соиіум. 2010. № 3. С. 124-132.

2. Баранов С. О. Ухилення від сплати податків як основний чинник тіньової економіки. Інвестииіï: практика та досвід. 2016. № 12. С. 102-106.

3. Вавілов П. М. Ухилення від сплати податків в Україні: причини виникнення та шляхи подолання проблеми. Науковий вісник Херсонського державного університету. 2013. № 2. С. 24 27.

4. Введение автоматического обмена финансовой информацией в Украине в 2020 году: как подготовить бизнес к первому обмену? [Електронний ресурс]. URL: https://attorneys.ua/ru/publication/introduction-ofautomatic-exchange-of-financial-information-in-ukr /

5. Главацька Н. І. Визначення передумов та наслідків ухилення від сплати податків. Управління розвитком. 2016. № 21. С. 79-81.

6. Дубровський В., Черкашин В., Порівняльний аналіз фіскального ефекту від застосування інструментів ухилення / уникнення оподаткування в Україні. Київ, 2017. [Електронний реcypc]. URL: https://rpr.org.ua/wp-content/uploa.pdf

7. Кузнецова Т. Е., Хавина С. А. Неформальный сектор экономики: структура, масштабы, противоречивость функций и результатов. Москва: М-Студио, 2008. 456 с.

8. Лібанова Е. М., Баланда А. Л. Неформальний сектор ринку праці: визначення та методи оцінки. Зайнятість та ринок прайі. 1998. Вип. 6. С. $245-246$.

9. Майбуров И. А., Соколовская А. М. Теория налогообложения. Продвинутый курс: учебник для магистрантов, обучающихся по спе- 
циальностям "Финансы и кредит", "Бухгалтерский учет, анализ и аудит". Москва: ЮНИТИДАНА, 2011. 591 с.

10. Методологічні положення щодо визначення неформальної зайнятості населення / Наказ Державної служби статистики України від 23.01.2013 № 16 [Електронний ресурс]. - URL: http://www.ukrstat.gov.ua

11. Мірошніченко О. В. Використання офшорних механізмів ухилен-ня від сплати податків серед загроз економічній безпеці України. Вісник економічної науки України. 2011. № 1 (19). C. 88-94.

12. Попович В. М. Тіньова економіка як предмет економічної кримінології. Київ: Правові джерела, 1998. 448 с.

13. Проект Закону №3131-1 «Про внесення змін до Податкового кодексу України та деяких інших законодавчих актів України щодо удосконалення системи оподаткування у сфері земельних відносин і сільського господарства» від 17.03.2020. [Електронний ресурс]. URL: https://w1.c1.rada.gov.ua/pls/zweb2/webproc4_1?id= \&pf3511=68409

14. Томнюк Т. Л. Ухилення від оподаткування: сутність, методи реалізації та економічні наслідки. Сталий розвиток економіки: 2011. Вип. 3. С. 279-282.

15. Ліхоносова Г. С., Чаплигін I. К. Концепція систематизації фінансових результатів підприємства: обліково-аналітичні аспекти забезпечення. Часопис економічних реформ. 2021. № 1 (41). C. 58-66.

\section{References}

1. Angelko, I. (2010). Informal employment of the population of Ukraine in modern conditions. Ukrainian society, 3, 124-132.

2. Baranov, S. O. (2016). Tax evasion as a major factor in the shadow economy. Investments: practice and experience, 2, 102-106.

3. Vavilov, P. M. (2013). Tax evasion in Ukraine: causes and ways to overcome the problem. Scientific Bulletin of Kherson State University, 2, 24 27.

4. Introduction of automatic exchange of financial information in Ukraine in 2020: how to prepare a business for the first exchange? [Retrieved from: https://attorneys.ua/en/publication/introdu -in-

\footnotetext{
Стаття надійшла

до редакції : 11.02.2021 p.
}

ukraine-in-2020-how-shall-the-business-prepareitself-for- the-first-exchange /

5. Hlavatka, N. I. (2016). Determination of preconditions and consequences of tax evasion. Development management, 21, 79-81.

6. Dubrovsky, V., Cherkashin, V. (2017). Comparative analysis of the fiscal effect of the use of instruments of tax evasion / avoidance in Ukraine. Kyiv. Retrieved from: https://rpr.org.ua/wpcontent/uploads/2018/02/Instrumenty-uhylyannyavid-splaty-podatkiv-2017-1.pdf

7. Kuznetsova, T. E., Khavina, S. A. (2008). Informal sector of the economy: structure, scale, inconsistency of functions and results. Moscow: MStudio, 2008. 456 p.

8. Libanova, E. M., Balanda, A. L. (1998). Non-formal sector of the labor market: definition and evaluation methods. Employment and labor market, 6 , 245-246.

9. Mayburov, I. A., Sokolovskaya, A. M. (2011). Theory of taxation. Advanced course: a textbook for undergraduates majoring in "Finance and Credit", "Accounting, Analysis and Auditing". Moscow: UNITI-DANA, 591.

10. Methodological provisions for determining the informal employment of the population / Order of the State Statistics Service of Ukraine dated 23.01.2013 № 16. Retrieved from: http://www.ukrstat.gov.ua

11. Miroshnichenko, O. V. (2011). The use of offshore mechanisms of tax evasion among the threats to the economic security of Ukraine. Bulletin of Economic Science of Ukraine, 1(19), 88-94.

12. Popovych, V. M. (1998). Shadow economy as a subject of economic criminology. Kyiv: Pravovi dzherela, 448.

13. Draft Law №3131-1 “On Amendments to the Tax Code of Ukraine and Certain Other Legislative Acts of Ukraine Concerning the Improvement of the Tax System in the Sphere of Land Relations and Agriculture" of March 17, 2020. Retrieved from: https://w1.c1.rada.gov.ua/pls/zweb29

14. Tomnyuk, T. L. (2011). Tax evasion: essence, methods of implementation and economic consequences. Sustainable development of the economy, 3, 279-282.

15. Likhonosova, G. S., Chaplygin, I. K. (2021). The concept of systematization of financial results of the enterprise: accounting and analytical aspects of support. Time description of Economic Reforms, 1(41), 58-66.

Стаття прийнята

до друку: 30.06.2021 p.

\section{Бібліографічний опис для цитування :}

Ліхоносова Г. С. Соціально-відповідальні аспекти адміністрування податків: важелі протидії ухиленню від оподаткування / Г. С. Ліхоносова, К. Р. Мартиненко // Часопис економічних реформ. - 2021. - № 2 (42). - С. 39-47. 